\title{
Analysis of Financial Management Problems and Countermeasures in College Students' Start-up Enterprises
}

\author{
Xie Jianru ${ }^{1}$, Guo Yintong ${ }^{2}$, Dong Jian ${ }^{3, *}$ \\ ${ }^{1}$ School of Accounting Department, Guangdong Polytechnic of Water Resources and Electric Engineering, Guangzhou, \\ Guangdong 510635, China \\ ${ }^{2}$ International School, Guangdong Food and Drug Vocational College, Guangzhou, Guangdong 510520, China \\ ${ }^{3}$ School of Management, Guangdong Food and Drug Vocational College, Guangzhou, Guangdong 510520, China \\ *Corresponding author. Email: 315287054@qq.com
}

\begin{abstract}
As more and more college students graduate, employment has become a social problem. The employment situation is severe and the competition is fierce. Therefore, many college students choose to set up their own enterprises, which can not only solve the employment problem, but also realize their social value. However, due to the lack of financial management knowledge and insufficient attention to financial management among college students, most start-ups fail to start a business. Financial management plays a very important role in college students' start-up enterprises, which directly determines the success or the failure of entrepreneurship. This paper first briefly introduces the background of college students' start-up enterprises, expounds the importance of financial management in the start-up enterprises, and then analyzes the financial management knowledge that college students should master and the financial management problems, finally proposes countermeasures against these problems, in order to ensure the sustainable development of college students on the entrepreneurial road.
\end{abstract}

Keywords: College Students, start-ups, financial management issues, countermeasures

\section{INTRODUCTION}

Entrepreneurship of college students is a trend in colleges and universities, and it is an important way to cultivate talents in colleges and universities. Since the slogan of "mass entrepreneurship and innovation" in China was put forward, a series of relevant entrepreneurship policies have been issued to encourage college students to start their own businesses. Encouraged by favourable entrepreneurship policies, college students' entrepreneurship has become less difficult and complicated, and their dreams have become a reality.

However, according to relevant statistics, the success rate of college students' entrepreneurship is less than $5 \%$, which seriously affects their enthusiasm for entrepreneurship. The success of college students' entrepreneurship is influenced by many factors, including external factors, such as the relevant national entrepreneurship policy, social environment and economic environment. There are also internal factors, such as college students' own quality, interpersonal skills, management skills, entrepreneurial skills, capital factors, financial management factors, of which financial management plays the most important role. Therefore, it is particularly important to analyze the financial management in the start-up enterprises of college students, so as to improve the success rate of the start-ups and enthusiasm of college students.

\section{THE SIGNIFICANCE OF FINANCIAL MANAGEMENT IN START-UP ENTERPRISES}

\subsection{Financial management is the basic condition of college students' start-up enterprises}

College students need start-up capital first, regardless of the size of enterprises. Start-up capital is the basic condition of start-up enterprises, just like the blood of an enterprise, which directly affects the success of the startups. In order for a startup to run well, it must actively and effectively raise funds, use and allocate funds in a scientific and reasonable way, and withdraw funds in a timely manner. However, due to the lack of experience in starting a business, college students are faced with many problems when starting a business, especially the problem of capital. Also, college students usually fail to make scientific and reasonable allocation and planning of capital, which often leads to capital shortage, and dilemma of enterprises. 


\subsection{Financial management runs through every period of college students' start-up enterprises}

From the idea of setting up a business to scale expansion of the start-ups, college students cannot do without capital in every period. Capital is the category of financial management, so a start-up cannot do without financial management naturally. Financial management runs through every period of the enterprise and plays a very important role, including the raising of capital in the early stage, the use and distribution of capital in the middle stage, and the payment of employees' wages and salaries in each period. Also, capital is needed in the publicity of the start-ups, the production and sales, and the reimbursement of all kinds of expenses. Capital is like the heart of an enterprise. Only when it is used reasonably, legally and effectively can the enterprise develop sustainably.

\subsection{Financial management determines the success of the start-ups}

An enterprise must have legal and effective financial management system in order to run well. The success of college students' start-up enterprises mainly depends on their operating results. To determine the final profit or loss of the enterprise, it is needed to analyze the financial activities of the enterprise, through accounting to obtain the final profit and loss data. When an enterprise grows to a certain size and wants to expand, it must reach a conclusion through financial analysis and risk assessment. Only through financial management, can the enterprise correctly grasp the current decision right and wrong, to make the enterprise to continue to develop and grow[1].

\section{THE NECESSARY FINANCIAL MANAGEMENT KNOWLEDGE FOR COLLEGE STUDENTS TO START ENTERPRISES}

\subsection{Revenue management}

Revenue refers to the total inflow of economic benefits formed in the daily activities of the enterprise, which will lead to the increase of owners' equity and has nothing to do with the capital invested by the owners. College students' start-ups, no matter how big or small, and what kind of projects they invest in, are bound to generate more or less revenue. If a business has no revenue, that means it doesn't generate economic benefits, then the business has no value to exist. College students should pay special attention to the revenue management.

\subsection{Expenditure management}

Expenditure refers to the total outflow of an enterprise's assets in the process of production and operation for the purpose of obtaining another asset and paying off debts. If an enterprise wants to run normally, it cannot do without expenditure, which is to get more revenue. To run a business, there will be many kinds of expenses, such as wages for employees; payments or prepayments for materials, office supplies; the outflow of assets to repay bank loans, accounts payable, and to pay accounts or dividends; expenditures incurred for the purchase of fixed assets and the payment of long-term project costs and consumer expenditures in daily life. Without systematic financial management of these expenditures, it is likely to affect the normal operation of the enterprise, and may also bring losses to the enterprise. In particular, the start-up enterprises of college students are inexperienced. If they do not carry out systematic financial management of expenditure, they may die in the initial stage. When college students start up a business, they should make a budget for the expenditure with no extravagance and waste, and try their best to control the expenditure, so that the enterprise can develop sustainably for a long time.

\subsection{Cash management}

Cash management refers to the capital activities in the normal operation of an enterprise, such as the budget, collection and expenditure of the funds needed by the enterprise, as well as the investment of the enterprise. To run a business, cash is indispensable. It is very important for college students to do a good job in cash management.

\subsection{Financial statement management}

Financial statements refer to the documents provided by an enterprise to reflect the financial position of the enterprise on a specific date and the operating results, cash flow and other accounting information of an accounting period. It includes accounting statements and their notes and other relevant information and materials that should be disclosed in financial statements. However, most college students may know income management, expenditure management, cash management, but very few know financial statement management. Financial statements can provide financial information for decisions made by enterprises and their current and potential investors, creditors, and other users of financial accounting reports. Therefore, if college students want to succeed in start-ups, they must strengthen their knowledge of financial statements, which plays an important role in the long-term development of enterprises. 


\section{FINANCIAL MANAGEMENT PROBLEMS OF COLLEGE STUDENTS' START-UP ENTERPRISES}

\subsection{Lack of adequate financial management awareness}

In the early stage of college students' start-ups, the scale of enterprises is small with a little amount of capital investment and bad management. Due to the small scale, the most basic and original financial accounting method is adopted[2]. This basic accounting method often cannot fully reflect the financial activities of the enterprise, which will make the enterprise face financial crisis and lead to the bankruptcy of the enterprise. Financial management is an important link in the normal operation of an enterprise, and the reasonable and effective establishment of financial management system can help the enterprise to achieve the maximization of interests and sustainable development. However, due to no experience, college students' start-up enterprises usually blindly focus on the production and sales of the enterprises, while make a unreasonable plan for the financial management of the enterprises out of lacking adequate financial management awareness. At the same time, because most of the enterprises set up by college students are small in scale and have single business, they have low requirements on financial management, and generally only set cashier, reimbursement and simple accounting positions.

\subsection{Lack of financial management knowledge}

College students have the advantage of innovation consciousness, flexible way of thinking, abundant knowledge and skills. But in the aspect of starting a business, their financial management knowledge is far from enough. There are a lot of problems in the early stage of the start-ups, and the shortage of capital is the most serious problem. In order to establish an enterprise, college students should not only care about the normal operation of the enterprise and the sales of products, but also learn more about financial management. Financial management is an important part of the normal operation of an enterprise. Whether the managers of an enterprise master sufficient financial management knowledge directly affects the success of the enterprise.

\subsection{Lack of sound financial management system}

Due to the shortage of funds, instead of employing experienced financial management personnel to engage in financial work, college students' start-up enterprises often assign some ordinary management personnel to be financial management personnel at the same time. Because these part-time workers are not familiar with financial knowledge, it is easy for them to keep too simple records of current funds, with inaccurate records of costs and expenses. They sometimes may even miss and misrecord. In this way, the start-ups lack phased and systematic planning for financial management, thus affecting the financial decision of the enterprise. Therefore, in order to succeed, college students' start-ups must establish a sound financial management system, and professional financial management personnel should lead the enterprise to develop.

\subsection{Lack of reasonable and effective financing channels}

Sufficient capital can help the enterprise to develop and grow rapidly. However, most college students themselves are lack of capital, and also it is very difficult to borrow money from financial institutions or seek investment, so most of them borrow money from their parents, relatives and friends, who cannot afford enough for a start-up. Without reasonable and effective financing channel, even college students have excellent project and business plan, it is all useless. College students' start-up enterprises lack experience, so the start-up risks are high and the expected benefits are not clear. As a result, the domestic financing market either takes a wait-and-see attitude towards college students' start-ups or puts forward high financing requirements, which makes some promising enterprises unable to develop.

\subsection{Lack of reasonable financial arrangements}

College students are generally enthusiastic when they start up an enterprise, believing that they have enough ability to carry out business and that their enterprises will be successful. However, the reality is cruel, because college students generally lack experience in starting a business, many enterprises cannot continue to operate. In addition to the lack of experience, the most important reason is that there is no reasonable arrangement of funds and no reasonable plan for the use of funds. In order to successfully establish an enterprise, it is necessary to reasonably arrange the use and expenditure of capital, for example, how much capital should be used for investment? for development? or for turnover? All these require a reasonable and complete budget arrangement. If the startups lack reasonable capital arrangement, the enterprise is doomed to be unable to operate for a long time.

\subsection{Lack of effective market research}

College students usually conduct proper market research to see whether the enterprises and projects they are going to set up are feasible. However, due to the lack of a comprehensive and systematic understanding of the 
market, the market research done in advance is very onesided and incomplete, which may lead to the failure of the start-ups. Even if they do enough research in advance, since the market is changing rapidly, college students lack enough awareness of risk, so they cannot effectively avoid risk, which may still make the enterprise fail to continue to develop smoothly.

\section{COUNTERMEASURES ANALYSIS OF FINANCIAL MANAGEMENT PROBLEMS OF COLLEGE STUDENTS' START-UP ENTERPRISES}

\subsection{Strengthen the awareness of financial management}

Financial management is the key to the operation and development of an enterprise. It is the management of the purchase of assets (investment), the financing of capital (financing) and the cash flow from operations (working capital) and the distribution of profits under certain overall objectives. Financial management is an integral part of enterprise management. It is an economic management work that organizes enterprise financial activities and deals with financial relations in accordance with financial laws and regulations and the principles of financial management. Financial management plays an important role in every stage of college students' start-up enterprises, and is an important factor for the success of college students' startups. College student start-ups need to raise start-up capital, use and allocate funds, which are all areas of financial management. The implementation of reasonable and scientific financial management is conducive to the effective operation of enterprise funds, the establishment of an effective operating mechanism, and the implementation of a complete financial budget management, which plays a very important role in improving the management level of enterprises and the economic benefits of enterprises[3]. Therefore, if college students want to set up their own enterprises successfully, they should not only learn financial management knowledge, but also strengthen the awareness of financial management, so as to avoid risks and achieve long-term development of enterprises.

\subsection{Strengthen the study of financial management knowledge}

College students should learn more about financial management knowledge, understand the basic accounting concepts of enterprises, master the basic accounting methods of enterprises, learn to understand financial statements, and strive to improve their financial analysis ability. At the same time, it is necessary to hire professional financial personnel to join the management team, because they have a wealth of financial management knowledge, and plays a very positive role in the start-up enterprises. They can also strengthen the financial management knowledge of ordinary employees, improve the overall quality of all staff, to ensure the smooth development of the enterprise.

\subsection{Establish a sound financial management system}

Most students got their start-up capital on their own. Although they pay attention to team consciousness, cooperation spirit, but due to the lack of social experience, and shortage of capital, they don't have spare money to hire professional financial management personnel, let alone establish a financial management system. A reasonable and effective financial management system can maximize the interests of enterprises. Therefore, college students' start-up enterprises must establish a sound financial management system. Perfect financial management system can promote the formation of the college students' start-ups internal control mechanism, can control the costs and expenses of the enterprise, can reduce consumption, thus realize the scientific and rational use of enterprise funds, and improve the effect of the use of funds[4]. It can also prevent financial fraud and guard against financial risks, improve the enterprise's financial control ability, guarantee the students' start-ups to longterm health.

\subsection{Increase financing channels}

When college students start up enterprises, they should make a detailed analysis of the capital needs according to the development needs of different stages of the enterprises. In the early stage, the scale of the enterprise is relatively small, and college students can raise start-up funds through family and friends. In the middle stage, the enterprise develops to a certain scale and has a good reputation, so it can borrow money from the bank by way of mortgage. Although college students have a relatively single source of financing when they start up a business, they can still find ways to increase financing channels, such as improving their understanding of financing knowledge and increasing the amount of micro-loans. In addition, college students can also have a good understanding of the country's preferential policies for entrepreneurship to conduct financing, including the preferential policies for entrepreneurship, such as the corresponding national tax relief, government interest, employment incentives[5]. College students' start-up enterprises should not only open source, but also reduce expenditure, which will bring great convenience to enterprise financing. 


\subsection{Lack of sound financial management system}

If college students can make rational investment in start-up enterprises, it can greatly reduce investment risks and improve the success rate of enterprise establishment. College students' start-up enterprises must establish the awareness of investment risk, do market research, understand the risk ratio of investment enterprises, and understand the probability that enterprises may encounter risks in the early and mid-stage. At the same time, the risk response plan should be made to prevent the occurrence of risk when we do not know how to respond. After college students start up a business, they should always keep the risk awareness and make rational investment, which can effectively prevent risks and ensure the good development of the enterprise[6].

\subsection{Optimize the entrepreneurial environment}

College students' start-up enterprises can not only realize their own social value, but also relieve employment pressure, which is good for the country. Therefore, the country should lower the policy threshold, extend the preferential period, increase the intensity of tax incentives, so that more entrepreneurial enterprises enjoy preferential national policies. Secondly, the government should encourage financial institutions to provide small unsecured loans to college students' entrepreneurs, or the government should provide guarantees to start-up enterprises, encourage private investment institutions and enterprises to provide financial support to college students, regulate the crowdfunding behavior of third-party platforms, and reduce the difficulty and risk of financing college students. Finally, the government can intensify the policy publicity through the power of new media, launch the mobile APP of government departments, set up the WeChat official account and the official Weibo account, etc., so as to make it easier for college students to get the latest policy information[7].

\section{CONCLUSION}

As an important social development talent, college students are the backbone of the country, and the hope of the country. College students' self-employment can not only solve the problem of difficult employment, but also realize their social value. So enterprise financial management problems in college students' start-ups should not be a hard time. College students should strengthen the financial management consciousness, grasp enough knowledge of financial management, broaden the financing channels, establishing scientific investment decision-making mechanism, promote the enterprise sustainable development.

\section{ACKNOWLEDGMENT}

This work was sponsored by Guangdong Provincial Philosophy and Social Science "13th five-year plan" 2016 Discipline Co-construction Project (Grant No. GD16XGL08), the Key Humanities and Social Science Research Project of Guangdong Food and Drug Vocational College 2019(Grant No. 2019RW01).

\section{REFERENCES}

[1] Sui Yan, Wu Yunfei. Financial management problems and countermeasures of college students' selfemployment $[\mathrm{J}]$. Operation and management.2016 (08 ) :157-159.

[2] Zhang Yuexu. Problems and countermeasures in financial management of college students' entrepreneurial activities $[\mathrm{J}]$ The financial times.2016(35):190-192.

[3] Liu Haoqi, Yu Haomin. Discussion on the financial management of college students' self-employment enterprises [J]. Science and technology innovation guide.2016(31): 168-170.

[4] Xu Xiaoxue. Financial management problems and countermeasures in the entrepreneurial process of college students[J]. Accounting study.2019(30):64-65.

[5] Wang Linlu, Wang Shijie, Zhang Xun. Investigation and research on financial management problems in the entrepreneurial process of college students[J]. Science Tribune. 2018(3):184-185.

[6] Yang Huipu. Business must pay attention to the issue of financial management[J]. The modern enterprise.2019(5):133-134.

[7] Lai Min, Zhang Baohua, Sui Shanshan. Research on enterprise financial management in pioneer park for college students -- a case study of Ji An vocational and technical college[J]. Chinese and foreign entrepreneurs. 2018(26):207-208. 